Науковий вісник НлТУ України Scientific Bulletin of UNFU

https://nv.nltu.edu.ua

https://doi.org/10.36930/40310303

Article received 12.04.2021 p.

Article accepted 29.04.2021 p.

UDC 630.450
ISSN 1994-7836 (print)

ISSN 2519-2477 (online)

$@ \bowtie$ Correspondence author

A. A. Novak

novak@nltu.edu.ua

А. А. Новак, О. Б. Михайлів, П. Б. Хоєџький, С. Л. Копій, І. В. Фізик, В. О. Агій

Національний лісотехнічний університет Украйни, м. Львів, Украӥна

\title{
ОСОБЛИВОСТІ ФОРМУВАННЯ КЛІМАТУ ПІВНІЧНО-ЗАХІДНОГО ПОДІЛЛЯ ТА ЇХ ВПЛИВ НА ВЕДЕННЯ ЛІСОВОГО ГОСПОДАРСТВА В РЕГІОНІ
}

\begin{abstract}
Наведено динаміку та проаналізовано закономірності змін основних кліматичних характеристик за 40-річний період в умовах Північно-західного Подільського лісогосподарського району Західноукраїнського лісостепового лісогосподарського округу. За останні десятиліття інтенсивно зростають середньорічна та середньомісячна за вегетаційний період температура повітря та кількість опадів, зменшується відносна вологість повітря, стрімко зростають обсяги санітарних (вибіркових і суцільних) та лісовідновних рубок. Із змінами клімату істотно пов'язані певні загрози (вітровали, пожежі, сніголами, вогнища збудників хвороб і шкідників) та негативні наслідки для лісового господарства (зміни продуктивності та стійкості лісостанів, зростання обсягів рубок лісу). В основі таких глобальних узагальнювальних висновків лежать численні результати досліджень у різноманітних регіонах і природних зонах. Виявлено тенденцію до зростання температури повітря та кількості опадів у досліджуваному регіоні. Кількість опадів тут зросла від 597,4 мм (за норми 551,0 мм) до 868,8 мм, середньорічна температура повітря - від 7,3 до 8,9 ${ }^{\circ} \mathrm{C}$. Упродовж останнього десятиліття кількість опадів за вегетаційний період зросла від 488,3 до 579,7 мм за середньої багаторічної норми за аналогічний період 391 мм. Зростання впродовж усього періоду досліджень кількості опадів від 597,4 мм у 1981-1990 рр. до 675,1 мм у 2001-2010 рр. на динаміці температури не позначилося. З'ясовано також, що впродовж останніх 40 років у Північно-західному Поділлі знижується вологість повітря. Середньорічна відносна вологість повітря зростала тільки впродовж 1981-2000 pp. - від 78,8 до 79,2 \%. Упродовж 2001-2020 pp. iї значення знизилось до $76,4 \%$. Особливо відчутним було зниження вологості повітря за вегетаційний період - від 74,6\% у 1981 1990 pp. до 70,3 \% у 2011-2020 pp., що є на 4,4 \% менше за багаторічну норму. За період 1981-2020 pр. найтеплішим i, водночас, найсухішим вегетаційним періодом характеризується останнє десятиліття, середньомісячна температура повітря у вегетаційний період якого становила $15,3^{\circ} \mathrm{C}$, а відносна вологість повітря - 70,3 \%. Встановлено, що внаслідок змін клімату у лісостанах триває тенденція до посилення патологічних процесів, зростання обсягів та інтенсивності санітарно-оздоровчих заходів. Інтенсивність вибіркових санітарних рубок істотно залежить від кількості опадів та сонячної активності. Зростання обсягів суцільних санітарних рубок пов'язане зі зниженням вологості повітря та кількості опадів.
\end{abstract}

Ключові слова: зміна клімату; кліматичні показники; санітарні рубки; сонячна активність.

\section{Вступ}

Зміни клімату, що відбуваються за останні десятиліття, істотно впливають на біосферу загалом та на лісові екосистеми зокрема. Існують різноманітні методики оцінювання та прогнозування цих кліматичних змін. За даними С. М. Семенова та інших авторів [17], які у своїй роботі узагальнюють літературні джерела та власні розрахунки, середня температура повітря за останні $100-140$ років зросла на $0,6^{ \pm 0,2}{ }^{\circ} \mathrm{C}$, причому підвищення температури у XX ст. було значнішим, ніж у будь-якому іншому столітті останнього тисячоліття, а 1990-ті роки виявились найтеплішим десятиріччям. 31950 р. частота екстремально низьких температур скоротилась, а екстремально високих - зросла. Упродовж XX ст. кількість опадів збільшувалась у середніх і високих широтах північної півкулі зі швидкістю 0,5-1 \% за 10 років, тоді як у субтропіках навпаки, зменшувалась зі швидкістю 0,3 \% за 10 років; у середніх і високих широтах північної півкулі у другій половині ХХ ст. часто-

Інформація про авторів:

Новак Анатолій Анатолійович, канд. с.-г. наук, доцент, кафедра лісівництва. Email: novak@gmail.com; https://orcid.org/0000-0003-1239-7423

Михайлів Оксана Богданівна, канд. с.-г. наук, доцент, кафедра лісівництва. Email: o.mychayliv@gmail.com; https://orcid.org/0000-0002-6794-9670

Хоєцький Павло Богданович, д-р с.-г. наук, професор, кафедра лісівництва. Email: hpb@ua.fm; https://orcid.org/0000-0001-9726-953X

Копій Сергій Леонідович, канд. с.-г. наук, доцент, кафедра лісівництва. Email: s.kopiy@email.ua; https://orcid.org/0000-0002-7322-7244

Фізик Irop Васильович, канд. с.-г. наук, доцент, докторант, кафедра екології. Email: igor240265@gmail.com; https://orcid.org/0000-0003-4247-2519

Агій Василь Омелянович, аспірант, кафедра екологіï. Email: agijvasyl@gmail.com; https://orcid.org/0000-0001-5840-9245

цитування за ДСтУ: Новак А. А., Михайлів О. Б., Хоєцький П. Б., Копій С. Л., Фізик І. В., Агій В. О. Особливості формування клімату Північно-Західного Поділля та їх вплив на ведення лісового господарства в регіоні. Науковий вісник НЛтУ України. 2021, т. 31, № 3. C. 22-26.

Citation APA: Novak, A. A., Mychayliv, O. B., Khoetskyi, P. B., Kopiy, S. L., Fizyk, I. V., \& Agii, V. O. (2021). The peculiarities of the climate formation of the North-Western Podillya and it influence on forestry in the region. Scientific Bulletin of UNFU, 31(3), $22-26$. https://doi.org/10.36930/40310303 
та екстремальної кількості опадів збільшилась на 2-4 \%. У цьому ж столітті збільшилась територія суші зі сильними посухами або надмірним зволоженням.

Із змінами клімату істотно пов'язані певні загрози (вітровали, пожежі, сніголами, вогнища збудників хвороб і шкідників) та негативні наслідки для лісового господарства (зміни продуктивності та стійкості лісостанів, зростання обсягів рубок лісу). В основі таких глобальних узагальнювальних висновків лежать численні результати досліджень у різноманітних регіонах і природних зонах.

Об'єкт дослідження - закономірності формування клімату.

Предмет дослідження - кліматичні характеристики та компоненти, що формують клімат у Північно-західному Подільському лісогосподарському районі Західноукраїнського лісостепового лісогосподарського округу.

Мета роботи - вивчити динаміку основних кліматичних характеристик Західного Лісостепу на прикладі північно-західного Поділля та виявити її вплив на стан і життєвість лісостанів.

Для досягнення зазначеної мети визначено такі основні завдання дослідження:

- проаналізувати динаміку кліматичних характеристик, охарактеризувати їх роль у формуванні клімату;

- оцінити вплив кліматичних і космічних чинників на санітарний стан лісостанів у досліджуваному регіоні;

- на підставі проведеного аналізу зробити відповідні висновки щодо регіональних кліматичних особливостей Північнозахідного Поділля та ведення лісового господарства 3 їх урахуванням.

Наукова новизна отриманих результатів досліджен$н я$ - вперше для умов Північно-західного Подільського лісогосподарського району проаналізовано регіональні кліматичні особливості, що мають значення для ведення лісового господарства та вивчено їх вплив на життєвість лісостанів i, як наслідок, на обсяги та інтенсивність санітарно-оздоровчих заходів.

Практична значущість результатів дослідження проведений аналіз дає змогу забезпечити комплексний та збалансований підхід до ведення господарства та багатоцільове використання лісових ресурсів регіону.

Аналіз останніх досліджень та публікацій. Особливості формування клімату України, зокрема її західної частини, детально вивчили вітчизняні вчені у різноманітних геофізичних, біологічних та екологічних аспектах. Так, зокрема ми, дослідили та проаналізували кліматотвірну складову для Малого Полісся, Розточчя та Опілля [9]. Прогностичне моделювання приземної температури на території України досліджували С. В. Краковська та ін. автори [8, 7]. Особливості атмосферної циркуляції над північною півкулею всебічно вивчила В. Ф. Мартазінова $[13,12,11]$. В.В.Лавний та В. Г. Мазепа [10] досліджували вплив сонячної активності на вітровали і буреломи лісу в Українських Карпатах та встановили зв'язок між числами Вольфа та обсягами суцільних вітровалів. Вплив сонячної активності на величину радіального приросту дерев у Західному та Малому Поліссі досліджував В. Г. Мазепа [15, 14]. Вплив середньорічних значень чисел Вольфа на вікові зміни швидкості вітру в приземному шарі атмосфери вивчала Н. І. Швень [18]. Авторка зазначає, що період швидкісного переміщення повітряних мас з 1891 по 1929 рр. збігається $з$ низьким рівнем сонячної активності. Сонячно-біосферні зв'язки грунтовно вивчив російський учений О. Л. Чижевський [4].
Матеріали та методи дослідження. Для аналізу закономірностей формування клімату в досліджуваному регіоні використали метеорологічні дані метеостанції Хмельницький, яка розташована у Північно-західному Подільському лісогосподарському районі Західноукраїнського лісостепового лісогосподарського округу [5], щодо середньомісячних значень температури повітря, місячних сум опадів, та відносної вологості повітря за 1981-2020 роки. Для встановлення обсягів санітарних рубок, які є основним заходом для підвищення стійкості та оздоровлення лісостанів, використано матеріали річної звітності (форми 10-ЛГ та 3-ЛГ) ДП "Старокостянтинівське ЛГ", яке є одним 3 провідних та найтиповіших лісогосподарських підприємств для досліджуваного регіону.

\section{Результати дослідження та їх обговорення}

У Північно-західному Поділлі впродовж останніх 40 років найменша кількість опадів (465,5 мм) випала у 1994 р., а найбільша (1257,4 мм) - у 2013 році. Мінімальну кількість опадів зафіксовано також у такі роки: 1984 (485,3 мм), 1986 (465,8 мм), 1990 (497,3 мм), 1999 (521,2 мм), 2003 (529,2 мм), 2009 (554,5 мм). Максимальну кількість опадів (понад 800 мм) зафіксовано у 2008 p. (870,9 мм), 2012 p. $\quad(1065,9$ мм), 2013 p. (1257,4 мм), 2016 p. (906,4 мм), 2017 p. (832,8 мм), 2018 p. (848,6 мм), 2020 р. (802,6 мм). Динаміку опадів за досліджуваний період наведено на рис. 1 .

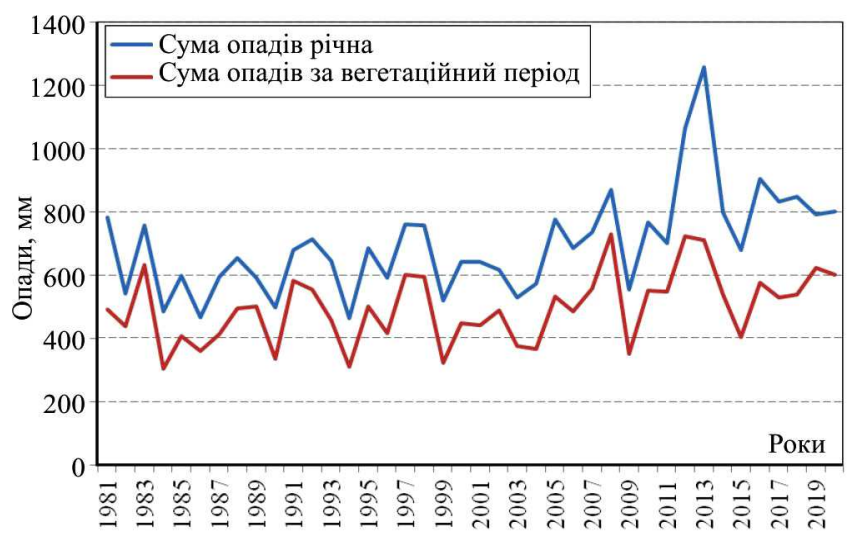

Рис. 1. Динаміка опадів за метеостанцією Хмельницький упродовж 1981-2020 pp.

Основні кліматичні показники розрахували за чотири десятирічні періоди, а їх середні багаторічні - за весь період досліджень 31981 р. до 2020 роки. (табл. 1). Як видно $з$ наведених даних, упродовж усього аналізованого періоду спостерігається тенденція до зростання температури повітря та кількості опадів. Кількість опадів зросла від 597,4 мм (за норми 551,0 мм) до 868,8 мм, середньорічна температура повітря - від 7,3 до $8,9^{\circ} \mathrm{C}$. Середньорічна відносна вологість повітря зростала тільки впродовж 1981-2000 pp. - від 78,8 до 79,2 \%. Упродовж 2001-2020 pp. iï значення знизилось до 76,4 \%. Особливо відчутним було зниження вологості повітря за вегетаційний період - від 74,6 \% у 1981-1990 рр. до 70,3 \% у 2011-2020 pp., що є на 4,4 \% менше за багаторічну норму. Загалом упродовж останніх 40 років у Північно-західному Поділлі триває тенденція до зниження вологості повітря та зростання температури. Зростання впродовж усього періоду досліджень кількості опадів від 597,4 мм у 1981-1990 рр. до 675,1 мм у 20012010 pp. на динаміці температури не позначилося. 
Табл. 1. Динаміка основних кліматичних показників за даними метеостанції Хмельницький

\begin{tabular}{|c|c|c|c|c|c|c|}
\hline \multirow{2}{*}{ Кліматичний показник } & \multicolumn{5}{|c|}{ Період, роки } & \multirow{2}{*}{\begin{tabular}{|c|} 
Середнє багаторічне \\
значення (до 1981 р.)
\end{tabular}} \\
\hline & $1981-1990$ & $1991-2000$ & $2001-2010$ & $2011-2020$ & $1981-2020$ & \\
\hline Температура повітря (середньорічн $a),{ }^{\circ} \mathrm{C}$ & $7,3^{ \pm 15,2}$ & $7,3^{ \pm 10,8}$ & $8,0^{ \pm 6,6}$ & $8,9^{ \pm 7,5}$ & $7,9^{ \pm 12,9}$ & 6,9 \\
\hline $\begin{array}{l}\text { Температура повітря (середня за вегета- } \\
\text { ційний період), }{ }^{\circ} \mathrm{C}\end{array}$ & $13,6^{ \pm 3,9}$ & $13,6^{ \pm 5,1}$ & $14,4^{ \pm 2,4}$ & $15,3^{ \pm 4,0}$ & $14,2^{ \pm 6,2}$ & 13,4 \\
\hline $\begin{array}{l}\text { Відносна вологість повітря (середньоріч- } \\
\text { на), \% }\end{array}$ & $78,8^{ \pm 1,9}$ & $79,2^{ \pm 2,3}$ & $78,1^{ \pm 1,7}$ & $76,4^{ \pm 2,7}$ & $78,1^{ \pm 2,5}$ & 78,8 \\
\hline $\begin{array}{l}\text { Відносна вологість повітря (середня за } \\
\text { вегетаційний період), \% }\end{array}$ & $74,6^{ \pm 3,2}$ & $74,3^{ \pm 3,6}$ & $72,9^{ \pm 3,4}$ & $70,3^{ \pm 3,8}$ & $73,0^{ \pm 4,1}$ & 73,5 \\
\hline Кількість опадів (середньорічн $a$ ), мм & $597,4^{ \pm 18,3}$ & $646,3^{ \pm 14,9}$ & $675,1^{ \pm 16,5}$ & $868,8^{ \pm 20,0}$ & $696,9^{ \pm 23,0}$ & 551,0 \\
\hline $\begin{array}{l}\text { Кількість опадів (середня за вегетаційний } \\
\text { період), мм }\end{array}$ & $438,2^{ \pm 22,1}$ & $479,4^{ \pm 22,4}$ & $488,3^{ \pm 23,4}$ & $579,7^{ \pm 16,0}$ & $496,4^{ \pm 22,6}$ & 391,0 \\
\hline
\end{tabular}

За період 1981-2020 pp. найтеплішим i, водночас, найсухішим вегетаційним періодом характеризується останнє десятиліття, середньомісячна температура повітря у вегетаційний період якого становила $15,3^{\circ} \mathrm{C}$, а відносна вологість повітря - 70,3\%. Упродовж останнього десятиліття кількість опадів за вегетаційний період зросла до 579,7 мм.

За даними кліматологів [6], 2007 р. за всю історію метеорологічних спостережень був найтеплішим майже на всій території України, а середньорічна температура повітря була вища за кліматичну норму на $2,1^{\circ} \mathrm{C}$. У Північно-Західному регіоні України середня температура повітря за останні роки зросла на $1,1-1,7{ }^{\circ} \mathrm{C}$ [19]. На думку вчених [3], збереження тенденції до глобального потепління призведе до змін у погоді, порушить усталене функціонування екологічних систем, згубно позначиться на природних ресурсах.

За останні десятиліття спостерігається закономірна зміна метеорологічних показників у часі (рис. 2 і 3). Причому впродовж аналізованого періоду середньорічна температура повітря за вегетаційний період щорічно зростала, в середньому на $0,1^{\circ} \mathrm{C}$, а середньорічна відносна вологість повітря знижувалась на $0,31 \%$.

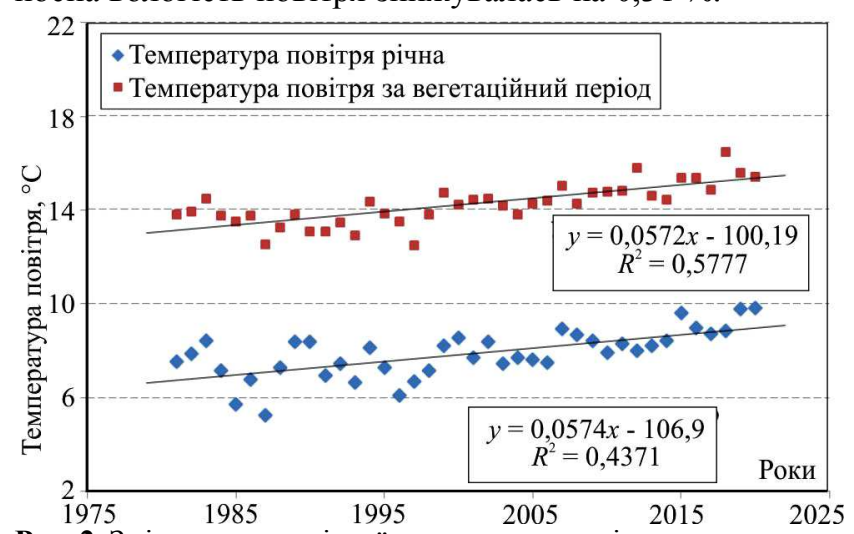

Рис. 2. Зміна середньорічної температури повітря за даними метеостанції Хмельницький упродовж 1981-2020 pp.

Підвищення за останні роки середньої температури повітря та кількості опадів також зафіксували польські дослідники, які вивчали динаміку метеорологічних показників на теренах Біловезької Пущі $[2,16]$. Автори констатують, що зростання температури повітря впливає на збільшення поверхневого випаровування та зумовлює, разом з посухами, зниження рівня грунтових вод на території заповідника.

За даними авторів $[1,6]$, настання весняного сезону, який починається переходом середньої добової температури повітря через $0{ }^{\circ} \mathrm{C}$, відбувається за останні роки на 16 днів раніше, ніж за кліматичною стандартною нормою. Чітка тенденція до раннього переходу, зумовлена, як зазначають В. Ф. Мартазінова та інші автори $[12,13]$, зміною великомасштабної циркуляції атмосфери і нетиповим розподілом теплових повітряних мас у тропосфеpi, що є наслідком глобального потепління клімату.

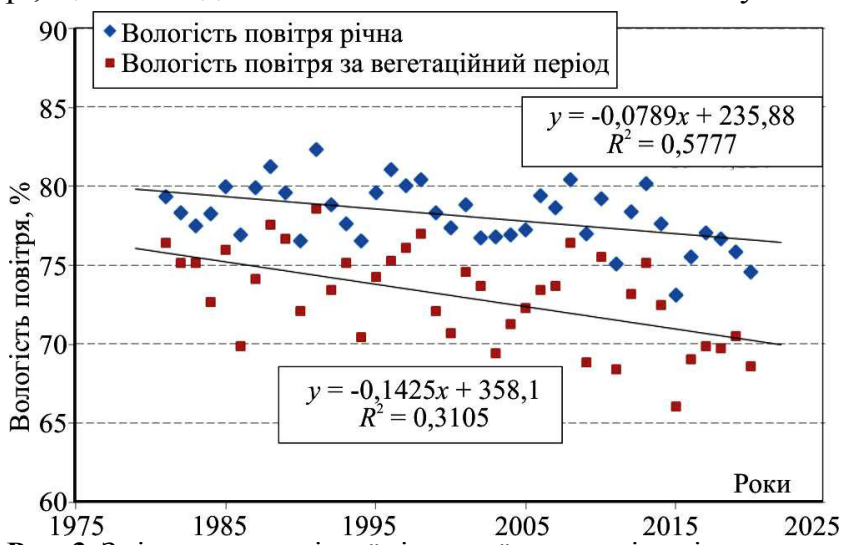

Рис. 3. Зміна середньорічної відносної вологості повітря за даними метеостанції Хмельницький впродовж 1981-2020 pp.

Здійснений аналіз залежності кліматичних показників Північно-західного Поділля від сонячної активності, виявив слабкі зв'язки середньої температури повітря та відносної вологості повітря за вегетаційний період 3 числами Вольфа (табл. 2). Коефіцієнти кореляції цих показників із сонячною активністю становлять відповідно 0,254 та 0,262. Дані щодо сонячної активності за досліджуваний період надано Центром Аналізу Даних Сонячного Впливу (http://www.sidc.be) Королівської Обсерваторії Бельгіï (https://www.astro.oma.be).

Сонячна активність має яскраво виражений циклічний характер 3 періодичністю у 10-12 років (рис. 4). Так, мінімальні значення чисел Вольфа відзначено у 1986 p. $(13,4) 1996$ p. $(8,6), 2008$ p. $(2,9)$ та 2019 p. $(3,6)$. Максимальна сонячна активність спостерігалась у 1989 p. (157,8), 2000 p. $(119,5), 2014$ p. $(113,6)$.

Табл. 2. Коефіціснти кореляції та регресії кліматичних показників метеостанції Хмельницыкий із сонячною активністю за період 1981-2020 pp.

\begin{tabular}{|c|c|c|c|c|}
\hline \multirow[t]{2}{*}{$\begin{array}{c}\text { Кліматичний } \\
\text { показник }\end{array}$} & \multirow{2}{*}{$\begin{array}{l}\text { Коефі- } \\
\text { цієнт ко- } \\
\text { реляції, } R\end{array}$} & \multirow{2}{*}{$\begin{array}{l}\text { Коефі- } \\
\text { цієнт ре- } \\
\text { гресії, } b_{y x}\end{array}$} & \multicolumn{2}{|c|}{$\begin{array}{c}\text { Критерій істотності } \\
\text { між порівнюваними } \\
\text { дисперсіями }\end{array}$} \\
\hline & & & $F_{\phi}$ & $F_{05}$ \\
\hline \multirow{2}{*}{$\begin{array}{l}\text { Середня темпера- } \\
\text { тура повітря }\end{array}$} & 0,254 & 0,005 & 1,935 & 0,175 \\
\hline & $\overline{0,148}$ & $\overline{-0,002}$ & $\overline{0,629}$ & $\overline{0,434}$ \\
\hline \multirow{2}{*}{$\begin{array}{l}\text { Відносна вологість } \\
\text { повітря }\end{array}$} & 0,027 & 0,001 & 0,021 & 0,887 \\
\hline & $\overline{0,262}$ & $\overline{0,013}$ & 2,068 & 0,161 \\
\hline \multirow{2}{*}{ Сума опадів } & 0,109 & $-0,235$ & 0,335 & 0,567 \\
\hline & $\overline{0,017}$ & $\overline{-0,036}$ & $\overline{0,008}$ & $\overline{0,928}$ \\
\hline
\end{tabular}

Примітка: у чисельнику наведено результати залежності за календарний рік, у знаменнику - за вегетаційний період. 
Здебільшого зростання та зниження вологості повітря, як середньорічної, так і за вегетаційний період, відбувається, відповідно, на фазах посилення та послаблення сонячної активності. Пікові значення вологості повітря фіксують або у роки з такими ж значеннями чисел Вольфа, або з відхиленням від них на 1-2 роки.

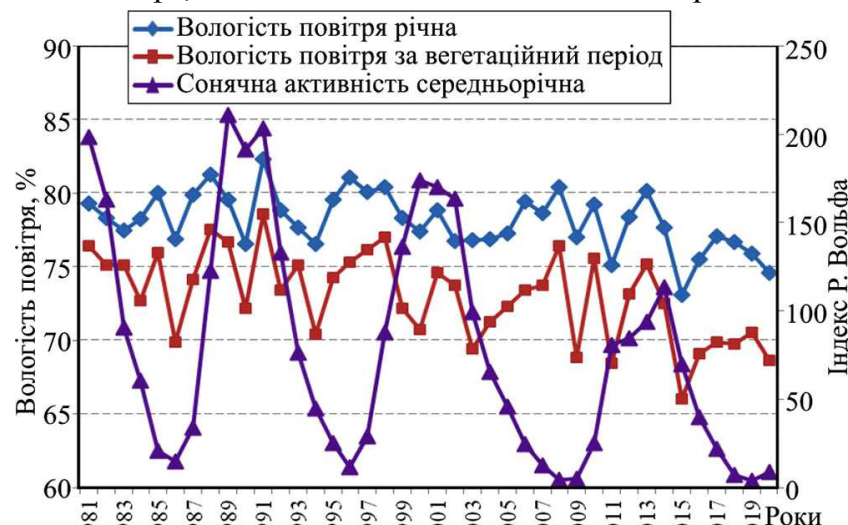

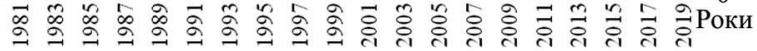

Рис. 4. Динаміка відносної вологості повітря за даними метеостанції Хмельницький на фоні середньорічних значень сонячної активності за 1981-2020 pp.

Варто також зазначити, що за 2001-2020 pр. у Північно-західному Поділлі середньорічна відносна вологість повітря не перевищувала 82,3\%, а впродовж вегетаційного періоду - 78,6 \%. Відтак можемо припустити, що підвищення температури та зменшення відносної вологості повітря спричинятиме формування посушливіших лісорослинних умов.

Унаслідок змін клімату у лісостанах триває тенденція до посилення патологічних процесів, зростання обсягів та інтенсивності вибіркових санітарних рубок (рис. 5). Так, за 2005-2016 рр. в умовах Північно-західного Поділля обсяг вибіркових санітарних рубок за окремі роки в 1,6-3,6 раза перевищує обсяги доглядових рубань, а їх інтенсивність зросла від 11,6 м³/га у 2005 р. до $17,9 \mathrm{~m}^{3} /$ га у 2015 році. Пікові значення інтенсивності вибіркових санітарних рубок ми зафіксували у 2011 та 2013 pp. - 21,8 та 21,4 м³/га відповідно.

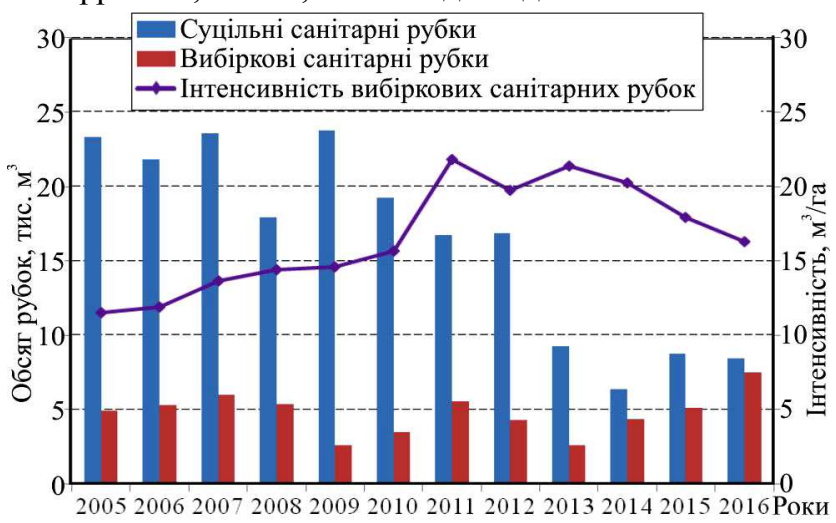

Рис. 5. Динаміка обсягів та інтенсивності санітарних рубок у

ДП "Старокостянтинівське ЛГ"

Для визначення тісноти зв'язку обсягів $(M)$ та інтенсивності $(I)$ санітарно-оздоровчих заходів із сонячною активністю $(W)$, опадами $(R)$, температурою $(T)$ та вологістю $(F)$ повітря, ми виконали кореляційний аналіз залежності між цими показниками, результати якого наведено в табл. 3. Зростання обсягів суцільних санітарних рубок пов'язане зі зниженням вологості повітря та кількості опадів, що підтверджується помірним оберненим зв'язком $(r=-0,45)$ між цими показниками станом на рік обліку. Інтенсивність вибіркових санітарних рубок також істотно залежить від кількості опадів та сонячної активності (коефіцієнти кореляції 0,47 та 0,87 відповідно).

Табл. 3. Кореляція обсягів та інтенсивності санітарних рубок у ДП "Старокостянтинівське ЛГ" із кліматичними показниками за період 200-2016 pp.

\begin{tabular}{|c|c|c|c|c|}
\hline Показник & $W$ & $R, \mathrm{мM}$ & $F, \%$ & $T,{ }^{\circ} \mathrm{C}$ \\
\hline $\mathrm{M}(\mathrm{CCP}), \mathrm{m}^{3}$ & $-0,75$ & $-0,45$ & 0,32 & $-0,48$ \\
\hline $\mathrm{M}(\mathrm{BCP}), \mathrm{m}^{3}$ & $-0,15$ & $-0,16$ & $-0,35$ & 0,34 \\
\hline $\mathrm{I}(\mathrm{BCP}), \mathrm{m}^{3} / г \mathrm{a}$ & 0,87 & 0,47 & $-0,23$ & 0,23 \\
\hline
\end{tabular}

Вплив сонячної активності та опадів на інтенсивність вибіркових санітарних рубок свідчить про те, що в період іï зростання спостерігається тенденція до погіршення санітарного стану лісів (рис. 6). Водночас, надмірна кількість опадів (понад 1100 мм) також негативно впливає на життєвість деревостанів, навіть на фазах спаду сонячної активності.

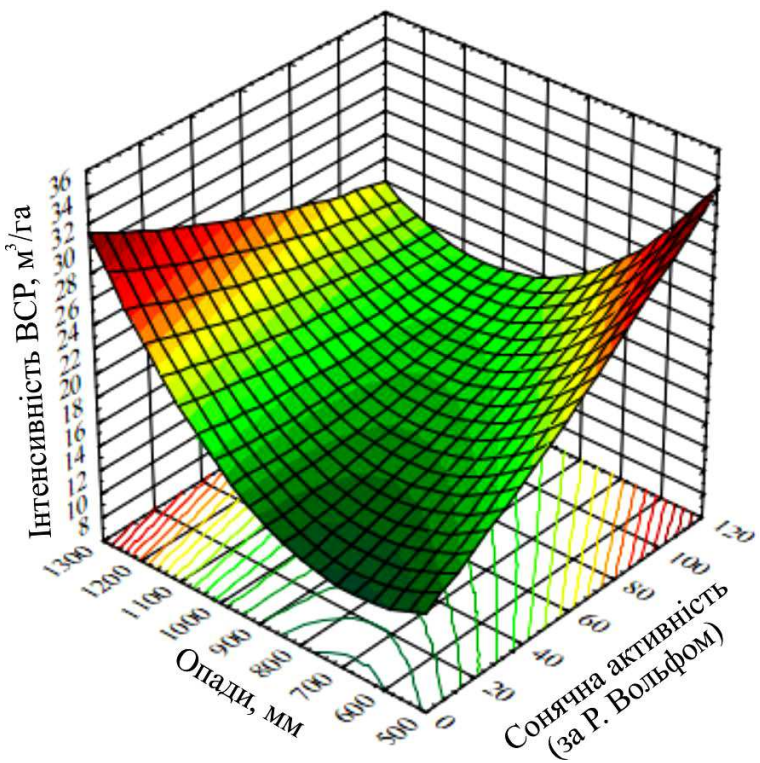

Рис. 6. Залежність інтенсивності вибіркових санітарних рубок у ДП "Старокостянтинівське ЛГ" від сонячної активності та опадів за період 2005-2016 pp.

\section{Висновки}

1. Зміни клімату в умовах Північно-західного Поділля, які проявляються за останні десятиріччя, характеризуються інтенсивним зростанням температури повітря, як середньорічної, так і середньомісячної за вегетаційний період, кількості опадів та зменшенням відносної вологості повітря.

2. За період 1981-2020 pр. найтеплішим i, водночас, найсухішим вегетаційним періодом характеризується останнє десятиліття, середньомісячна температура повітря у вегетаційний період якого становила $15,3{ }^{\circ} \mathrm{C}$, а відносна вологість повітря - 70,3\%. Упродовж останнього десятиліття кількість опадів за вегетаційний період зросла до 579,7 мм.

3. Зростання та зниження вологості повітря, як середньорічної, так і за вегетаційний період, відбувається, відповідно, на фазах посилення та послаблення сонячної активності. Пікові значення вологості повітря фіксують або у роки з такими ж значеннями чисел Вольфа, або з відхиленням від них на 1-2 роки.

4. Унаслідок змін клімату у лісостанах триває тенденція до посилення патологічних процесів, зростання обсягів та інтенсивності санітарно-оздоровчих заходів. 
5. Вплив сонячної активності та опадів на інтенсивність вибіркових санітарних рубок свідчить про те, що iii зростання негативно позначається на санітарному стані лісів.

6. Обсяги санітарних рубок у лісостанах Західного Лісостепу є похідними від негативного впливу змін клімату і зростають в періоди посилення сонячної активності. Для прогнозування обсягів санітарних рубок, санітарного стану лісів доцільно враховувати встановлену тісну залежність інтенсивності санітарних рубок від сонячної активності за числами Вольфа.

\section{References}

1. Babichenko, V. M., Nikolaieva, N. V., Rudishyna, S. F., \& Hushchyna, L. M. (2009). Nastannia vesnianoho sezonu v Ukraini (perekhid serednoi dobovoi temperatury povitria cherez $0^{\circ} \mathrm{S}$ ) $\mathrm{v}$ umovakh suchasnoho klimatu. Ukrainian Geographical Journal, 1, 25-35. [In Ukrainian].

2. Boczon, A. (2006). Charakterystyka warunków termiczno-pluwialnych w Puszczy Bialowieskiej w latach 1950-2003. Les. Prace Bad, 1, 57-72. [In Polish].

3. Boichenko, S. H., Voloshchuk, V. M., \& Doroshenko, V. M. (2000). Hlobalne poteplinnia ta yoho naslidky. Ukrainian Geographical Journal, 2, 59-68. [In Ukrainian].

4. Chyzhevskyi, A. L. (1995). Kosmycheskyi puls zhyzny. Moscow, 806 p. [In Russian].

5. Hensiruk, S. A. (2002). Lisy Ukrainy. Lviv. 496 p. [In Ukrainian].

6. Kosovets, O. O., \& Pakhaliuk, O. Ye. (2008). Osoblyvosti temperaturnoho rezhymu Ukrainy u 2007. Pratsi TsHO, 4(18), 7-10. [In Ukrainian].

7. Krakovska, S. V., Palamarchuk, L. V., Shedemenko, I. P., Diukel, H. O., \& Hnatiuk, N. V. (2008). Veryfikatsiia danykh Svitovoho Klimatychnoho Tsentru (CRU) ta rehionalnoi modeli klimatu (REMO) shchodo prohnozu pryzemnoi temperatury povitria za kontrolnyi period 1961-1990. Scientific works of UkrNDHMI, 257, 42-60. [In Ukrainian].

8. Krakovskaia, S. V., Palamarchuk, L. V., \& Diukel, H. A. (2008). Rehyonalnaia model (REMO) v yzuchenyy sylnыkh osadkov v Karpatakh. Meteorolohiia, klimatolohiia ta hidrolohiia, 50, 7580. [In Russian].
9. Krynytskyi, H. T., Mazepa, V. H., Novak, A. A., \& Dankevych, S. M. (2013). Dynamichni tendentsii klimatu Zakhidnoho Lisostepu Ukrainy ta yikh vplyv na sanitarnyi stan lisostaniv. Kyiv. Scientific reports of the NUBiP of Ukraine, 187(1), 254-263. [In Ukrainian].

10. Lavnyi, V. V., \& Mazepa, V. H. (2013). Vplyv soniachnoi aktyvnosti na vitrovaly i burelomy lisu v Ukrainskykh Karpatakh. Scientific Bulletin of UNFU, 23(3), 97-103. [In Ukrainian].

11. Martazynova, V. F., \& Ostapchuk, V. V. (2004). Vzaimozavisimost' processov cirkulyacii v troposfere i stratosfere pri kratkovremennyh i dlitel'nyh potepleniyah i poholodaniyah v Ukraine. Scientific works of UkrNDHMI, 253, 27-36. [In Russian].

12. Martazynova, V. F., Yvanova, E. K., \& Chaika, D. Yu. (2006). Izmenenie krupnomasshtabnoj atmosfernoj cirkulyacii na protyazhenii XX veka i ee vliyanie na pogodnye usloviya i regional'nuyu cirkulyaciyu vozduha v Ukraine. Geofizicheskij zhurnal, 28(1), 51-60. [In Russian].

13. Martazynova, V. F., Yvanova, E. K., \& Chaika, D. Yu. (2007). Izmenenie atmosfernoj cirkulyacii v Severnom polusharii v techenii perioda global'nogo potepleniya $\mathrm{v}$ XX veke. Ukrainian Geographical Journal, 3, 10-19. [In Russian].

14. Mazepa, V. H. (2011). Lisovi nasadzhennia Zakhidnoho i Maloho Polissia v umovakh aerotekhnohennoho zabrudnennia ta osoblyvosti vedennia hospodarstva v nykh: Doctoral Dissertation for Agricultural Sciences (06.03.03 - Silvics and forestry). Lviv, 379 p. [In Ukrainian].

15. Mazepa, V. H., Krynytskyi, H. T., \& Leontiak, H. P. (2009). Naslidky vplyvu zmin klimatu ta atmosfernoho zabrudnennia na radialnyi pryrist sosniakiv v umovakh Maloho Polissia Ukrainy. Scientific Bulletin of UNFU, 19(15), 56-63. [In Ukrainian].

16. Pierzgalski, E., Boczon, A., \& Tyszka, J. (2002). Zmiennosc opadov i polozenia wod gruntowych w Bialowieskim Parku Narodowym. Kosmos. Problemy Nauk Biologicznych, 4, 415-425. [In Polish].

17. Semenov, S. M., Yasiukevych, V. V., \& Helver, E. S. (2006). Vyyavlenie klimatogennyh izmenenij. Moscow: Meteorologiya i gidrologiya, 324 p. [In Russian].

18. Shven, N. I., \& Petrenko, K. V. (2006). Zalezhnist vikovykh zmin shvydkosti vitru v pryzemnomu shari atmosfery vid kharakteru tsyrkuliatsiinoi epokhy i soniachnoi aktyvnosti. Pratsi Tsentralnoi heofizychnoi observatorii, 2(16), 52-56. [In Ukrainian].

19. Yeremieiev, V., \& Yefimov V. (2003). Rehionalni aspekty hlobalnoi zminy klimatu. Bulletin of the NAS of Ukraine, 2, 14-19. [In Ukrainian].

A. A. Novak, O. B. Mychayliv, P. B. Khoetskyi, S. L. Kopiy, I. V. Fizyk, V. O. Agii

Ukrainian National Forestry University, Lviv, Ukraine

\section{THE PECULIARITIES OF THE CLIMATE FORMATION OF THE NORTH-WESTERN PODILLYA AND IT INFLUENCE ON FORESTRY IN THE REGION}

The dynamics and regularities of changes in the main climatic characteristics over a 40 -year period in the North-Western Podillya forestry district of the Western Ukrainian forest-steppe forestry district are presented. In recent decades, the average annual and average monthly air temperature and precipitation during the growing season have been growing rapidly, relative humidity has been declining, and there is a sharp increase in the volume of sanitary (selective and continuous) and reforestation. Climate change is significantly associated with certain threats such as winds, fires, snowstorms, outbreaks of pathogens and pests and also negative consequences for forestry, in particular changes in productivity and resilience of forests, and increasing deforestation. Such global generalizing conclusions are based on numerous research findings in various regions and natural areas. The tendency to increase the air temperature and precipitation in the studied region is revealed. The amount of precipitation here increased from $597.4 \mathrm{~mm}$ (at the norm of $551.0 \mathrm{~mm}$ ) to $868.8 \mathrm{~mm}$, the average annual air temperature ranges from $7.3^{\circ} \mathrm{C}$ to $8.9^{\circ} \mathrm{C}$. Over the last decade the amount of precipitation during the growing season has increased from $488.3 \mathrm{~mm}$ to $579.7 \mathrm{~mm}$ with an average long-term norm for the same period of $391 \mathrm{~mm}$. The increase during the entire research period in the amount of precipitation from 597.4 mm in 1981-1990 years to $675.1 \mathrm{~mm}$ in 2001-2010 years did not affect the dynamics of temperature. The research has also found that humidity has been declining in North-Western Podillya for the past 40 years. The average annual relative humidity increased only during 19812000 years - from $78.8 \%$ to $79.2 \%$. During 2001-2020 years its value decreased to $76.4 \%$. The decrease in humidity during the growing season was especially noticeable - from $74.6 \%$ in $1981-1990$ years to $70.3 \%$ in $2011-2020$ years, which is $4.4 \%$ less than the long-term norm. During the period 1981-2020 years the warmest and at the same time the driest growing season is characterized by the last decade, the average monthly air temperature during the growing season was $15.3{ }^{\circ} \mathrm{C}$, and the relative humidity was $70.3 \%$. It is revealed that due to climate change in forest stands there is a tendency to intensify pathological processes, increase the volume and intensity sanitary and health measures. The intensity of selective sanitary felling largely depends on the amount of precipitation and solar activity. The increase in the volume of continuous sanitary felling is associated with a decrease in humidity and precipitation.

Keywords: climate change; climatic indicators; sanitary fellings; solar activity. 